\title{
Skal vi behandle åpentstående ductus?
}

Ductus arteriosus er et embryonalt kar og danner i fosterlivet en forbindelse fra arteria pulmonalis til aorta descendens, slik at blodet ledes utenom de intrauterint funksjonsløse lungene. Forbindelsen lukkes normalt i timene etter fødselen, men hos for tidlig fødte barn forsinkes ofte lukkeprosessen - resultatet blir en persisterende ductus arteriosus (PDA). Denne kan forårsake en betydelig venstre-høyre-shunt med hjertesvikt, overperfusjon av lungene og underperfusjon av øvrige organer, noe som har mange uheldige konsekvenser.

Persisterende ductus arteriosus er en av de vanligste utfordringene i prematuritetsmedisinen (forekommer hos ca. $40 \%$ av barn med fødselsvekt under $1000 \mathrm{~g}$ ). Tilstanden er tradisjonelt blitt behandlet med kirurgisk lukning og/eller medikamentell lukning med ikkesteroide antiinflammatoriske legemidler (indometacin eller ibuprofen). Nyere forskning har satt spørsmålstegn ved både nytten av og risikoen forbundet med disse behandlingsformene, slik Bratlid \& Farstad beskriver i en oversiktsartikkel i dette nummer av Tidsskriftet (1). Dette har gitt opphav til en markant diskusjon i internasjonale fagmiljøer og stor variasjon i klinisk praksis: Enkelte sentre gir nesten utelukkende konservativ behandling (væskerestriksjon, ventilasjonsstøtte) (2), slik også Bratlid \& Farstad argumenterer for, mens andre gir profylaktisk medikamentell behandling til alle for tidlig fødte barn under en viss gestasjonsalder (3).

Slik faglig uenighet er en viktig påminnelse om den usikkerhet og subjektivitet som preger all medisinsk praksis, også på områder med betydelig vitenskapelig innsats. Dette skyldes at praksis alltid influeres av holdninger; i denne sammenhengen dreier det seg blant annet om etiske og vitenskapsteoretiske standpunkter. Tilhengerne av konservativ persisterende ductus arteriosus-behandling argumenter både ut ifra primum non nocere-prinsippet og ut ifra prinsippet om at randomiserte, placebokontrollerte studier og tilhørende metaanalyser bør tillegges større vekt enn andre erkjennelsesmetoder $(1,4)$. Sagt mer konkret: De krever en dokumentert positiv langtidseffekt på harde endepunkter som død og nevrologisk sekvele før de er villige til å utsette premature pasienter for potensiell risikofylt behandling.

Det er viktig å minne om at selv om antiinflammatoriske legemidler lukker persisterende ductus arteriosus på en effektiv måte, er ikke det i seg selv en tilstrekkelig begrunnelse for behandling dersom pasienten ikke blir friskere på lang sikt. Men et rendyrket konservativt standpunkt er også problematisk. Konsekvensene ved å avstå fra behandling er heller ikke godt dokumentert. Man vet lite om det naturlige forløpet av persisterende ductus arteriosus hos premature barn. En nylig publisert retrospektiv studie med over 300 pasienter indikerer imidlertid en betydelig overdødelighet, også når man korrigerer for mulige konfunderende faktorer (5). Mange vil derfor, i likhet med Bratlid \& Farstad, argumentere for at man bør gjøre noe ved symptomgivende persisterende ductus arteriosus, for eksempel gi væskerestriksjon, ventilasjonsstøtte, ev. vanndrivende legemidler og pressorstoffer. Det er da fort gjort å møte seg selv i døren, for heller ikke slik intervensjon har vært gjenstand for randomiserte, dobbeltblinde studier av langtidseffekt og -risiko.

Det viktigste argumentet mot dogmatisk «Cochrane-isme» gjelder imidlertid validiteten av kliniske utprøvninger, som i stor grad forusetter et standardisert pasientmateriale. Persisterende ductus arteriosus hos premature representerer imidlertid et kontinuum, fra betydningsløse shunter til livstruende tilstander med kompleks patofysiologi og tallrike komplikasjoner. At en positiv langtidseffekt av generell profylaktisk behandling ikke lar seg dokumentere, utelukker $i k k e$ at samme type behandling kan være livreddende hos enkeltpasienter med alvorlig persisterende ductus arteriosus. Fremtidige intervensjonsstudier bør derfor konsentrere seg om effekten hos veldefinerte undergrupper av pasienter (6). Validitetsproblemet blir likevel ikke eliminert. Enhver indikasjonsstilling innebærer også en individuell vurdering av underliggende patofysiologi og aktuell hemodynamikk. En bedre kartlegging, med ekkokardiografi, hjerneperfusjonsundersøkelser og biokjemiske markører, vil kunne forbedre beslutningsgrunnlaget og gi mer skreddersydd behandling (6-8).

Etter vårt skjønn gjenspeiler norsk nyfødtmedisinsk praksis på dette feltet en fornuftig middelvei. Bratlid \& Farstads artikkel er en viktig påminnelse om behovet for vitenskapelig dokumentasjon. Men å snakke om et «paradigmeskifte» er å sette saken unødig på spissen $-\mathrm{i}$ alle fall her til lands.

\section{Vegard Bruun Wyller}

vegard.bruun.wyller@rikshospitalet.no

Inger Elisabeth Silberg

inger.elisabeth.silberg@rikshospitalet.no

Vegard Bruun Wyller (f. 1972) er dr.med., spesialist i barnesykdommer og overlege ved Barnehjerteseksjonen, Barneklinikken, Oslo universitetssykehus, Rikshospitalet.

Inger Elisabeth Silberg (f. 1951) er spesialist i barnesykdommer og overlege ved Nyfødseksjonen, Barneklinikken, Oslo universitetssykehus, Rikshospitalet.

Oppgitte interessekonflikter: Ingen

Litteratur

1. Bratlid D, Farstad T. Persisterende ductus arteriosus hos for tidlig fødte barn. Tidsskr Nor Lægeforen 2009: 129: 1455-8.

2. Vanhaesebrouck S, Zonnenberg I, Vandervoort P et al. Conservative treatment for patent ducturs arteriosus in the preterm. Arch Dis Child Fetal Neonatal Ed 2007: 92: 244-7.

3. Clyman RI, Saha S, Jobe A et al. Indomethacin prophylaxis for preterm infants: the impact of 2 multicentered randomized controlled trials on clinical practice. J Pediatr 2007; 150: 46-50.

4. Bose CL, Laughon MM. Patent ductus arteriosus: lack of evidence for common treatments. Arch Dis Child Fetal Neonatal Ed 2007; 92: 498-502.

5. Noori S, McCoy M, Friedlich P et al. Failure of ductus arterious closure is associated with increased mortality in preterm infants. Pediatrics 2009; 123: e138-44.

6. McNamara PJ, Sehgal A. Towards rational management of the patent ductus arteriosus: the need for disease staging. Arch Dis Child Fetal Neonatal Ed 2007: 92: $424-7$

7. El-Khuffash A, Barry D, Walsh K et al. Biochemical markers may identify preterm infants with a patent ductus arteriosus at high risk of death or severe intraventriclar haemorrhage. Arch Dis Child Fetal Neonatal Ed 2008; 93: 407-12.

8. Holstrøm H. Hall C, Thaulow E. Plasma levels of natriuretic peptides and hemodynamic assessment of patent ductus arteriosus in preterm infants. Acta Paediatr 2001; 90: 184-91. 